\title{
RELEVANSI MATERI MATA KULIAH BODI OTOMOTIF DAN MATERI MATA PELAJARAN TEKNIK PERBAIKAN BODI OTOMOTIF DENGAN MATERI UJI KOMPETENSI STANDAR BSNP
}

\author{
Muhammad Yusup Kurnia ${ }^{1}$, Amay Suherman ${ }^{2}$, Ariyano $^{3}$ \\ Departemen Pendidikan Teknik Mesin \\ Universitas Pendidikan Indonesia \\ Jl. Dr. Setiabudhi No. 207 Bandung 40154 \\ cingheu@gmail.com
}

\begin{abstract}
ABSTRAK
Tujuan relevansi yaitu terpenuhinya semua kebutuhan pengguna. Mengingat belum adanya pemetaan materi kurikulum secara komprehensip antara MK Bodi Otomotif, MPPKTPBO dengan UKK TPBO standar BSNP. Metode penelitian yang digunakan yaitu metode penelitian evaluasi dengan pendekatan discrepancy evaluation model. Fokusnya untuk mengukur adanya perbedaan antara yang seharusnya dicapai dengan yang sudah dicapai. Subyek dan tempat penelitian adalah SMKN 8 Bandung, DTM UPI dan dokumen BSNP. Temuan penelitian ini yaitu: materi MK Bodi Otomotif belum relevan terhadap materi MPPK TPBO di SMK 8 Bandung. Materi MK Bodi Otomotif belum relevan terhadap materi UKK TPBO standar BSNP. Materi MPPK TPBO sudah relevan terhadap materi UKK standar BSNP. Sekuen antara ketiga materi tersebut telah dipetakan.
\end{abstract}

Kata kunci: relevansi, pemetaan, sekuen, otomotif, standar

\begin{abstract}
This study contains a description of the material course, automotive body, subject matter expertise package, automotive body repair techniques and material skills competency test standard BSNP. Relevance here is the fulfillment of all the needs of the user. Reason implementation of this study is the lack of curriculum materials comprehensively mapping between MC Automotive Body, SMEP OBRT with UKK OBRT BSNP standards. The method used in this study is the evaluation of research methods to approach Discrepancy Evaluation Model. The findings of the study are: the material MC Automotive Body SMEP not relevant to the matter at SMKN 8 Bandung. The material MC Automotive Body material is not relevant to the standard UKK BSNP. The material was relevant to the material standards UKK BSNP. Generating sequence mapping between the three materials.
\end{abstract}

Keywords: relevance, mapping, sequence, automotive, standard

\section{PENDAHULUAN}

Rencana Pembangunan Jangka Menengah Nasional (RPJMN) tahun 2010-2014 yaitu rasio jumlah peserta didik Sekolah Menengah Atas (SMA) dan Sekolah Menengah

\footnotetext{
${ }^{1}$ Mahasiswa Departemen Pendidikan Teknik Mesin FPTK UPI

${ }^{2}$ Dosen Departemen Pendidikan Teknik Mesin FPTK UPI

${ }^{3}$ Dosen Departemen Pendidikan Teknik Mesin FPTK UPI
} 
Kejuruan (SMK) adalah 33\% berbanding 67\%. Upaya ini diharapkan bisa menjadi solusi untuk menyiapkan Sumber Daya Manusia yang siap bersaing dan memiliki kompetensi dibidang tertentu. Undang Undang No. 20 Tahun 2003 tentang Sistem Pendidikan Nasional Pasal 15: Pendidikan Menengah Kejuruan merupakan pendidikan yang mempersiapkan peserta didik untuk dapat bekerja dalam bidang tertentu. Artinya semakin banyak lulusan SMK diharapkan semakin banyak keterserapan lulusan dalam mendapat pekerjaan. Kenyataan di lapangan semakin bartambahnya lulusan SMK ternyata berbanding lurus dengan sumbangan tingkat pengangguran dari lulusan tersebut.

Pengangguran lulusan SMK pada bulan Agustus 2014 mengalami kenaikan dan menempati urutan pertama yakni 15,18 \% dari jumlah total lulusan sebanyak 2.172.720. Artinya produktifitas lulusan SMK paling rendah dibanding dengan tingkat lulusan yang lainya. Jika dibandingkan dengan lulusan SMU presentase jumlah TPK hanya 13,70\% dari jumlah total lulusan 3.400.793. Banyak faktor yang menyebabkan terjadi demikian satu diantaranya kualifikasi kemampuan lulusan SMK dengan kebutuhan dunia kerja masih ada kesenjangan. Masih ada kesenjangan kualitas dan relevansi antara lulusan SMK dengan dunia kerja. Renstra Ditjen Dikmen mengungkapkan masalah relevansi pendidikan masih menjadi pekerjaan rumah yang belum terselesaikan. Pendidikan menengah, khususnya pendidikan kejuruan, belum sepenuhnya sesuai dengan kebutuhan lapangan kerja. Meskipun sudah diberi bekal keterampilan, tidak semua lulusan SMK dapat bekerja. Banyak faktor yang mempengaruhi terhadap keberhasilan siswa salah satunya adalah guru.

Faktor guru sangat berpengaruh dalam dunia pendidikan. Di negara berkembang menunjukkan bahwa faktor guru memberikan sumbangan dalam prestasi belajar siswa sebesar $36 \%$, diikuti dengan faktor manajemen sebesar 23\%, faktor waktu belajar sebesar $22 \%$, dan faktor sarana fisik sebesar 19\% (Wagiran, 2009). Semakin tinggi tuntutan terhadap mutu pendidikan kejuruan semakin tinggi pula tantangan yang dihadapi guru kejuruan dan pendidikan guru kejuruan. Pendidikan kejuruan yang bermutu menuntut standarisasi gurunya. Guru yang berstandar membutuhkan pendidikan guru kejuruan yang berstandar pula. Secara tidak langsung peran lembaga pendidik dan tenaga kependidikan menentukan mutu pendidikan kejuruan.

UPI adalah salah satu LPTK yang di dalamnya terdapat Fakultas Teknologi dan Kejuruan. Departemen Pendidikan Teknik Mesin adalah departemen yang menyiapkan lulusannya untuk menjadi pendidik di Sekolah Menengah Kejuruan (SMK) Teknik Mesin. Hal itu terlihat dalam salah satu visinya yaitu menyelenggarakan pendidikan dalam lingkup Pendidikan Teknik Mesin untuk menyiapkan tenaga pendidik, profesional, yang berdaya 
saing global. Model pendidikan guru DPTM UPI umumnya menjaring siswa tamatan yang baru lulus SMA dan sederajat, yang sebagian besar belum memiliki pengalaman industri meskipun ada juga yang sudah bekerja di industri lalu melanjutkan ke DPTM. Untuk mendapatkan mutu guru yang standar dengan kebutuhan SMK dan dunia kerja sudah seharusnya kurikulum DPTM harus relevan dengan tuntutan tersebut. Jika suatu sekolah berfungsi menyiapkan tenaga pendidik bagi sekolah yang berada di bawahnya, maka sekolah tersebut perlu memahami kurikulum sekolah tersebut (Idi, 2014).

Artinya isi kurikulum DPTM harus memenuhi tuntutan SMK Teknologi. Sudah seharusnya pengembangan materi mata kuliah bidang keahlian sesuai dengan tuntutan materi pelajaran bidang keahlian yang ada di SMK Teknologi. Pengembangan kurikulum dilakukan dengan melibatkan pemangku kepentingan (stakeholders) untuk menjamin relevansi pendidikan dengan kebutuhan kehidupan, termasuk di dalamnya kehidupan kemasyarakatan, dunia usaha dan dunia kerja (BSNP, 2006). Belum adanya pemetaan materi kurikulum yang ideal khusus SMK dengan Perguruan Tinggi.

Tujuan dari penelitian ini untuk menghasilkan deskripsi relevansi materi mata kuliah Bodi Otomotif dengan materi mata pelajaran Teknik Perbaikan Bodi Otomotif SMKN 8 Bandung dan dengan materi UKK TPBO standar BSNP, menghasilkan deskripsi relevansi materi mata pelajaran paket keahlian Teknik Perbaikan Bodi Otomotif SMKN 8 Bandung dengan materi UKK TPBO standar BSNP serta menghasilkan pemetaan sekuen materi mata kuliah Bodi Otomotif DPTM UPI dengan materi mata pelajaran paket keahlian Teknik Perbaikan Bodi Otomotif SMKN 8 Bandung dengan materi UKK standar BSNP.

Secara umum arti dari relevansi adalah kecocokan. Relevan adalah bersangkut paut, berguna secara langsung. Relevansi ialah sesuatu sifat yang terdapat pada dokumen yang dapat membantu pengarang dalam memecahkan kebutuhan akan informasi (Reksoatmodjo, 2010). Relevansi merupakan sejumlah informasi terpanggil dalam sebuah pencarian pada koleksi perpustakaan atau sumber lainnya. Misalnya catalogue online atau basis data bibliografi, dimana informasi yang diberikan sesuai dengan subjek pada query dan relevan dengan kebutuhan pengguna.

Artinya dokumen dianggap relevan apabila isi dalam dokumen bisa membantu dan dapat memecahkan masalah. Relevansi artinya adanya kesatuan antara hasil pendidikan dengan tuntutan yang ada di masyarakat. Berdasar pada pendapat tersebut hasil pendidikan dikatan relevan ketika hasil pendidikan dibutuhkan dimasyarakat atau sesuai dengan tuntutan yang ada di masyarakat. Ada dua hal yang digunakan untuk mengukur relevansi yaitu recall dan precision. Pengertian sekuen (sequence) adalah sekumpulan atau sederetan 
pernyataan-pernyataan yang urutan dan pelaksanaan eksekusinya runtut, yang lebih dahulu ditemukan (dibaca) akan dikerjakan lebih dulu, dan yang terakhir ditemukan menjadi yang terakhir dikerjakan. Kemudian bila urutan pernyataan dibalik, sehingga akan memiliki makna yang berbeda (Ramdani, 2011)

Kurikulum diartikan sebagai rangkaian kegiatan dan pengalaman potensial (is/materi) yang telah disusun secara ilmiah, baik yang terjadi di dalam kelas, di halaman sekolah, maupun di luar sekolah atas tanggung jawab sekolah untuk mencapai tujuan pendidikan. Kurikulum diartikan sebagai jarak yang harus ditempuh oleh seorang pelari mulai dari start sampai finish untuk memperoleh medali/penghargaan. Kemudian, pengertian tersebut diterapkan dalam dunia pendidikan menjadi sejumlah mata pelajaran (subject) yang harus ditempuh oleh seorang siswa dari awal sampai akhir program pelajaran untuk memperoleh penghargaan dalam bentuk ijazah (Ruhimat, 2009).

Kurikulum adalah satu diantara alat untuk mencapai tujuan pendidikan, sekaligus merupakan pedoman dalam pelaksanaan pembelajaraan melalui dokumen tertulis yang mengandung isi mata pelajaran yang diajar kepada peserta didik di setiap jenjang pendidikan (Arifin, 2011). Sistem Pendidikan Nasional dalam Undang-undang Nomor 20 Tahun 2003 mengartikan kurikulum sebagai seperangkat rencana dan pengaturan mengenai tujuan, isi dan bahan pelajaran serta cara yang digunakan sebagai pedoman penyelenggaraan kegiatan pembelajaraan untuk mencapai tujuan pendididkan nasional dan khususnya pendidikan kejuruan.

Kurikulum sebagaimana yang telah dijelaskan oleh para ahli mengacu pada tujuan apa yang akan dicapai, dengan demikian dapat dikatakan bahwa kurikulum adalah suatu program pendidikan yang disediakan untuk membelajarkan peserta didik dengan berbagai macam cara proses pembelajaran. Program pendidikan mencakup mata pelajaran dan berbagai kegiatan belajar lainnya sehingga terjadi perubahan dan perkembangan tingkah laku peserta didik dalam mencapai nilai-nilai kehidupan yang diajarkan di sekolah (Hamalik, 2007).

\section{METODE PENELITIAN}

Metode yang digunakan pada penelitian ini adalah menggunakan metode penelitian evaluasi dengan pendekatan discrepancy evaluation model. Discrepancy evaluation model menekankan pada kesenjangan yang sebetulnya merupakan persyaratan umum bagi semua kegiatan evaluasi, yaitu mengukur adanya perbedaan antara yang seharusnya dicapai dengan yang sudah nyata dicapai. 


\section{HASIL PENELITIAN}

Hasil penelitian yang telah diperoleh yaitu relevansi materi mata kuliah Bodi Otomotif dengan mata pelajaran Perbaikan Panel-panel Bodi, dan relevansi materi mata kuliah Bodi Otomotif dengan materi mata pelajaran Pengecatan Bodi, bahwa materi mata kuliah Bodi Otomotif semuanya sesuai terhadap materi mata pelajaran Paket Keahlian TPBO namun ada 14 materi paket keahlian TPBO yang ada di SMK 8 Bandung belum tercover oleh materi mata kuliah Bodi Otomotif yang ada di DPTM UPI.

Relevansi materi mata kuliah Bodi Otomotif DPTM UPI dengan materi standar Uji Kompetensi Keahlian TPBO standar BSNP terdapat 15 materi UKK TPBO Standar BSNP yang belum terpenuhi oleh materi mata kuliah Bodi Otomotif. Semua materi UKK TPBO Standar BSNP sudah terpenuhi oleh materi mata pelajaran Paket Keahlian TPBO. Mata Kuliah Bodi Otomotif dengan materi UKK dan materi mata pelajaran Paket Keahlian TPBO dengan UKK dapat telah dipetakan sekuennya.

\section{PEMBAHASAN}

Relevansi materi mata kuliah Bodi Otomotif dengan materi mata pelajaran Pengecatan Bodi. Ditinjau dari keterpenuhan materi mata kuliah Bodi otomotif sedah memenuhi materi mata pelajaran Pengecatan Bodi. Jika suatu sekolah berfungsi menyiapkan tenaga pendidik bagi sekolah yang berada di bawahnya, perlu sekali sekolah tersebut memahami kurikulum sekolah tersebut. Jika dikaitkan pada prinsip pengembangan kurukulun ada prinsip relevansi eksternal, bahwa relevansi eksternal artinya kurikulum harus sesuai dengan tuntutan dan kebutuhan masyarakat. Kebutuhan dan tuntutan yang ada pada masa kini maupun kebutuhan yang diprediksi pada masa yang akan datang (Sukmadinata, 2009).

Relevansi materi mata kuliah Bodi Otomotif dengan mata pelajaran Perbaikan Panelpanel Bodi, dan relevansi materi mata kuliah Bodi Otomotif dengan materi mata pelajaran Pengecatan Bodi dapat disimpulkan bahwa materi mata kuliah Bodi Otomotif semuanya terpanggil terhadap materi mata pelajaran Paket Keahlian TPBO namun ada 14 materi paket keahlian TPBO yang ada di SMK 8 Bandung belum ter-cover oleh materi mata kuliah Bodi Otomotif yang ada di DPTM UPI. Artinya materi mata kuliah Bodi Otomotif belum relevan terhadap materi mata pelajaran Paket Keahlian TPBO.

Relevansi materi mata kuliah Bodi Otomotif DPTM UPI dengan materi standar Uji Kompetensi Keahlian TPBO standar BSNP berikut temuan dan pembahasan hasil 
penelitian. Terdapat 15 materi UKK TPBO Standar BSNP yang belum terpenuhi oleh materi mata kuliah Bodi Otomotif. Prinsip relevansi kurikulum ada empat jenis salah satunya relevansi pendidikan dengan dunia kerja. Gambaran dunia kerja dalam hal ini yakni UKK TPBO standar BSNP. Materi mata kuliah Bodi Otomotif yang ada di DPTM UPI belum relevan terhadap materi UKK TPBO standar BSNP, karena materi mata kuliah Bodi Otomotif Belum memenuhi kebutuhan materi UKK TPBO standar BSNP.

Ada sembilan kaidah kurikulum pendidikan kejuruan satu diantaranya kurikulum pendidikan kejuruan yang dinamis, adaftif, prediktif, dan fleksibel terhadap perubahan, dinamika sosial dan IPTEKS. Artinya kurukulum kejuruan harus mengikuti perkembangan saat ini. Tujuan kurikulum dirumuskan berdasarkan dua hal satu diantanya perkembangan tuntutan, kebutuhan dan kondisi masyarakat. Perkembangan tuntutan, kebutuhan dan kondisi masyarakat. Bardasarkan pemaparan di atas materi kuliah Bodi Otomotif harus ada penambahan materi terkait untuk memenuhi kebutuhan materi UKK TPBO standar BSNP (Sudira, 2006).

Semua materi UKK TPBO Standar BSNP sudah terpenuhi oleh materi mata pelajaran Paket Keahlian TPBO. Artinya materi mata pelajaran Perbaikan Panel-panel Bodi sudah relevan terhadap materi UKK standar BSNP. Karakteristik kurikulum SMK ada 10 karakteristik yang perlu diperhatikan dalam perencanaan kurikulum, dua diantanya standar keberhasilan dalam pekerjaan, hubungan antara sekolah dengan perindustrian dan masyarakat. Untuk mengevaluasi tujuan tersebut di SMK diadakan UKK, karena UKK adalah gambaran yang dipersyaratkan oleh industri. Tujuan dari diadakannya uji kompetensi salah satunya meningkatkan kualitas tamatan SMK sesuai dengan tuntutan kebutuhan dunia kerja (Subijanto, 2000). Materi mata pelajaran Paket Keahlian TPBO yang ada di SMK 8 Bandung sudah relevan karena sudah memenuhi kebutuhan materi UKK TPBO standar BSNP.

Perancangan pendidikan berbasis kompetensi didukung oleh lima konsep, satu diantaranya kompetensi dalam pendidikan atau competence in education. Kompetensi dalam pendidikan dan latihan dititik beratkan untuk menentukan profil pekerjaan dalam rangka menyusun peta struktur kompetensi yang komprehensif dan logis sesuai dengan peran tenaga kerja dalam pekerjaan tertentu. Kegiatan ini lazimnya dilakukan melaui analisis pekerejaan dan dituangkan dalam bentuk kurikulum pendidikan dan pelatihan kejuruan berbasis kompetensi. Menyusun peta struktur kompetensi yang komprehensif dan logis dituangkan dalam pemetaan sekuen. Ada beberapa cara untuk menyusun sekuens 
bahan ajar, yaitu: sekuens struktural, susunan materi pembelajaran yang mengandung strutur materi (Ari, 2012).

Pemetaan sekuen materi mata kuliah Bodi Otomotif, materi mata pelajara TPBO dan materi UKK standar BSNP telah petakan. Untuk memudahkan dalam pembacaan pemetaan materi telah terpetakan dengan secara lebih rinci sehingga dalam setiap pokok bahasan bisa dilihat pemetaaannya.

\section{KESIMPULAN}

Kesimpulan penelitian ini, yaitu, materi mata kuliah Bodi Otomotif yang terdapat di DPTM FPTK UPI belum relevan terhadap materi mata pelajaran Paket keahlian Teknik Perbaikan Bodi Otomotif, karena ada 14 materi mata pelajaran Paket Keahlian TPBO yang ada di SMK 8 Bandung yang belum terpenuhi oleh materi mata kuliah Bodi Otomotif yang di DPTM FPTK UPI. Materi mata kuliah Bodi Otomotif terdapat di DPTM FPTK UPI belum relevan terhadap kebutuhan materi UKK TPBO standar BSNP, karena ada 19 materi UKK yang belum terpenuhi oleh materi mata kuliah Bodi Otomotif. Relevansi materi mata pelajaran Paket keahlian Teknik Perbaikan Bodi Otomotif terdapat di SMK 8 Bandung sudah relevan terhadap materi UKK TPBO standar BSNP. Mata pelajaran Paket Keahlian Teknik Perbaikan Bodi Otomotif dan Standar Uji Kompetensi Keahlian Teknik Perbaikan Bodi Otomotif, dihasilkan pemetaan sekuen antara ketiga materi tersebut yaitu materi Kuliah Bodi Otomotif, materi mata pelajaran Paket Keahlian TPBO dan materi UKK standar BSNP.

\section{DAFTAR PUSTAKA}

Arifin, Z. (2011). Konsep dan Model Pengembangan Kurikulum. Bandung: Remaja Rosdakarya.

Ari, A. (2012). Pengantar Kurikulum [Online]. Diakses dari http://arifasari.blogspot.com /2012/03/pengantar-kurikulum.html.

BSNP. (2006). Panduan Penyusunan Kurikulum Tingkat Satuan Pendidikan Jenjang Pendidikan Dasar Dan Menengah. Jakarta: Direktorat Jendral Pendidikan Menengah Kementrian Pendidikan dan Kebudayaan.

Hamalik, O. (2007). Dasar-Dasar Pengembangan Kurikulum. Bandung: PT. Remaja Rosdakarya.

Idi, A. (2014). Pengembangan Kurikulum, Teori \& Praktik. Jakarta: Rajawali Pers 
Ramdani, F. (2011). Sekuen. [Online]. Tersedia di: https://farisrahmatramdani.wordpress. com/2011/04/18/sekuen/. Diakses 4 Desember 2014.

Reksoatmodjo, T. N. (2010). Pengembangan Kurikulum Pendidikan Teknologi Kejuruan. Bandung: PT Refika Aditama.

Ruhimat, T. (2009). Kurikulum dan Pembelajaran. Bandung: Jurusan Kurtekpend FIP UPI.

Subijanto. (2000). Uji Kompetensi Salah Satu Keunggulan Program Sistem Ganda. Jakarta: Badan Penelitian dan Pengembangan Pendidikan Nasional.

Sudira, P. (2006). Pembelajaran di SMK. Jakarta: Direktorat Pembinaan Sekolah Menengah Kejuruan.

Sukmadinata, N. S, (2009). Pengembangan Kurikulum: Teori dan Praktek. Bandung: Remaja Rosdakarya.

Wagiran. (2008). Pendidikan dan Peran Guru dalam Era Globalisasi. Prosiding Seminar Nasional Revitalisasi Peran UNY dalam Mewujudkan Tenaga Kependidikan Profesional (27-40). Yogyakarta: DPP IKA UNY. 